Proceedings of the 2018 International Scientific Conference 'Economic Sciences for Agribusiness and Rural Economy' No 1, Warsaw, 7-8 June 2018, pp. 396-401

\title{
ECO-INDUSTRIAL BANK ATTENDANCE TO ECO-INDUSTRIAL SYMBIOSIS
}

\author{
Grzegorz Paluszak, $\mathrm{PhD}^{1}$; Joanna Wiśniewska-Paluszak, $\mathrm{PhD}^{2}$ \\ ${ }^{1}$ Faculty of Economic Sciences, Warsaw University \\ ${ }^{2}$ Faculty of Economics, Poznań University of Life Sciences
}

\begin{abstract}
This article aims at conceptualization of new construct of eco-industrial bank and discusses its role in the development of eco-industrial symbiosis. The concept has been grounded in late theoretical streams of industrial ecology and industrial networks. The eco-industry bank plays a significant role of connecting ecology with business for the stakeholders' economic and social benefits. According to the concept the broad objectives of the bank are to use financial resources with economic, social and environmental responsibility and to give priority to environmental interaction with business and society.
\end{abstract}

Keywords: eco-industrial bank, eco-industrial symbiosis, industrial ecology JEL codes: Q57, G21, L14, Q01

\section{INTRODUCTION}

Nowadays, sustainable development is the most important challenge for each economic unit (Brundtland Commission, 1987). Preconditions of responsible business are connected with recognition of widespread interdependence of species and ecosystems, understanding of business performance beyond simple economic profits, and changing approach from shareholder to stakeholder (Kakabadse et al., 2005; Baraldi et al., 2010; Lee and Carroll, 2011; Porter and Derry, 2012; Iivonen and Moisander, 2014).

The literature highlights that exogenous incentives for responsible business may come from governmental policies or non-governmental organizations (Desrochers, 2001; Håkansson and Waluszewski, 2002). However, the Kalundborg Industrial
Park was never planned for industrial symbiosis, and it was spontaneously developed over a period of 20 years. The endogenous incentives of responsible business may come from successful business cooperation (Ehrenfeld and Gertler, 1997; Lowe, 2001, Bunjongsiri et al. 2015).

One of the most important incentive of sustainable development is financial support. Moreover, the need to provide investors with more objective, reliable and standardized information on loan performance (e.g. payback periods, return on investment, default rates) is being key to scaling up private sector interest in greening business and consumption (e.g. construction of passive houses). A large majority of the respondents to the public consultation considered that financial barriers are the most urgent to address, in particular regarding high upfront investment costs

\footnotetext{
${ }^{1}$ Corresponding author: Długa 44/50, 00-241 Warsaw, Poland, gpaluszak@wne.uw.edu.pl

${ }^{2}$ Corresponding author: Wojska Polskiego 28,60-637 Poznań, Poland, wisniew@up.poznan.pl
} 
and limited access to credit, too long payback times and credit risks (European Commission, 2013). In economies like Poland, additional constrains come into existence like: poor institutions, low environmental and social awareness of citizens and decision makers ( Kronenberg and Clift, 2005; Kronenberg and Bergier, 2012).

\section{THEORETICAL BACKGROUND}

Literature on environmental impacts of industry traditionally focused on the technological aspects. Today, the view shifts towards more holistic approach. Green industry deals with complexity of social, ecological and economic aspects (Dornfeld, 2012). The broadening of industrial ecology towards wider social and business dimensions lays in assumptions that environmental protection is more than the recycling of materials, sustainable development is more than environmental protection, transition towards sustainability requires the involvement of all business and social actors (Posch, 2010). Industrial ecology serves for: process and product design, defining industrial development, establishing new forms of cooperation, organizing material recycling in loop-closing systems, analysing industrial interdependencies, and creating holistic communities (Ayres and Ayres, 2002). Industrial symbiosis is the main object of study of industrial ecologists. It is the interrelationships among firms, as well as among their products and processes, at the local, regional, national, and global eco-systems (Chertow, 2000). The interacting industries may be collocated in a formal industrial symbioses or in informal industrial symbioses i.e. cooperate without any element of common management ( Ehrenfeld, and Gertler, 1997; Desrochers, 2001).

The inter-firm relationships are naturally transformed into a network structure. It is evident that industrial nodes can be connected by various types of ties including material and energy flows, financial transactions, information, and social interaction (Schiller et al., 2014; Velenturf and Jensen, 2015). Industrial symbiosis networks emerge as a series of symbiotic relationships between and among regional active ties and involve physical exchanges or material and energy carriers as well as the exchange of knowledge, human or technical resources, concurrently providing environmental and competitive benefits (Posch., 2010; Schiller et al., 2014; Li and Shi, 2015). Despite industrial ecology's primary interest in the functional ties that establish metabolism of the network, it also needs to consider indirect social influences, e.g. research institutes spreading knowledge, banks handing out loans or regulators introducing new regulations. Three patterns of network cooperation need financial activity of financial institutions: resource recovery networks without common investment, resource recovery networks with common investment, and energy cascading networks as a specific form of inter-company cooperation with common investment (Schiller et al., 2014). Consequently, the perspective of industrial organization and especially of industrial networks should be considered while identifying financial needs of implementing strategies to reduce the environmental impacts of products and processes associated with industrial systems.

New models of social and business analysis of material flows initiate the discussion on metabolic relationships in time and space which are produced and reproduced by social and business relationships (Ehrenfeld, 2004; Schiller et al., 2014). According to Ford and Håkansson (2006) the main feature of business relationships is interaction. The inherent characteristics of interacted network structures are interdependencies (Håkansson et al., 2009). In networks they are built mainly on technological, economic and resource dimensions. Jointness develops in many aspects: combined intentions, specific investments, mutual commitment, and common aims of network partners (Ford and Håkansson, 2002). The interactions evolve into temporal relationship with specific features typical for business. Håkansson and Snehota (1995) distinguished two main kinds of characteristics for business relationship: structural characteristics, as follows: continuity, complexity, symmetry and informality, and process characteristics, as follows: adaptations, cooperation and conflict, social interaction and rutinization. Mutual adaptations are a prerequisite of the development and continued existence of relationship between two companies. While business relationships are often complex and informal, they tend to become institutionalized over time. In 
networks technical development within one company and in its relationships is dependent on other companies' technologies. Social bonds that arise among individuals in the two companies are important for mutual trust and confidence in interaction between individuals.

To sum up, the recent achievements of industrial ecology and industrial networks approaches could serve as a good ground for discussions and conceptualisations of modern industrial eco symbiosis since they provide knowledge and tools for holistic design of environmental and business relationships of networking participants.

\section{MATERIALS AND METHODS}

This research has been carried on the ground of analysis of the recent literature on industrial ecology and industrial networks. It is followed by concluding on business relationships in eco-industrial symbiosis and the need of including financial institution in it. The main methods of the research are descriptive and deductive. The industrial ecology and industrial network approaches have been interrelated and applied in the study for conceptualizing business relationships of eco-industry bank with eco-industry companies in eco-industry symbiosis.

\section{RESULTS AND DISCUSSION}

Nowadays, environment is a key focus amongst industrial actors including banks which are namely 'green banks', 'ethical banks' or 'sustainable banks'. According to the Coalition for Green Capital (2014) the green bank is a public or quasi-public financing institution that provides low-cost, long-term financing support to clean, low-carbon projects by leveraging public funds through the use of various financial mechanisms to attract private investment so that public money supports multiple moneys of private investment. Other definitions of green bank underlines its different activities like: pushing ecoinnovativeness, expanding green investment, fostering environmentally responsible financing practices, introducing environmentally sustainable internal process, considering all the social and environmental issues, making this planet more habitable, promoting environment-friendly practices and reducing carbon footprint, protecting the environment and conserving natural resources (Habib, 2010; Schultz, 2010; Bai, 2011; Goyal and Joshi, 2011; Thombre, 2011; Azman, 2012; Bahl, 2012; Singh and Singh, 2012; Rahman and Barua, 2016).

Green banking is a concept of shifting banks' objectives from 'profit only' to 'profit with responsibility' (Rahman and Barua, 2016). Green banks are gradually coming to realize that there is a need for shift from the 'profit, profit and profit' motive to 'planet, people and profit' which in fact establishes the rationale for green banking (Verma, 2012). Therefore, 'green bank' which is wider considered as a 'sustainable bank' distinguish apart from conventional banks by concerning business, social and environmental impacts of all of its activities and business relationships by becoming a participant of different eco-industrial symbiosis. It is namely eco-industrial bank.

Eco-industrial bank is one of the three pillars of eco-industry (Fig. 1). It is assumed that it sets up longlasting business relationships with all stakeholders of eco-industrial symbiosis and undertakes only these interactions with clients which increase their sustainability through ecological accountability of activities. Industrial networks facilitate the material end energy flow transformation in the course of industrial ecology. Likewise, eco-bank facilitates the financial flows transformation in the course of industrial ecology. As a result informal and formal eco-industrial symbiosis come into existence. The eco-industrial symbiosis are the way of reaching sustainable development nowadays in many areas, in particular in food and agricultural industries.

Applying the industrial network approach, the eco-industrial symbiosis is defined as a group of business actors which undertake activities in an attempt to reduce waste and pollution, efficiently share and exchange resources such as information, materials, water, energy, infrastructure and natural resources, and help to achieve sustainable development, with the intention of increasing economic gains and improving environmental quality.

As the business relationships of eco-industrial bank and eco-industrial symbiosis evolve three types 


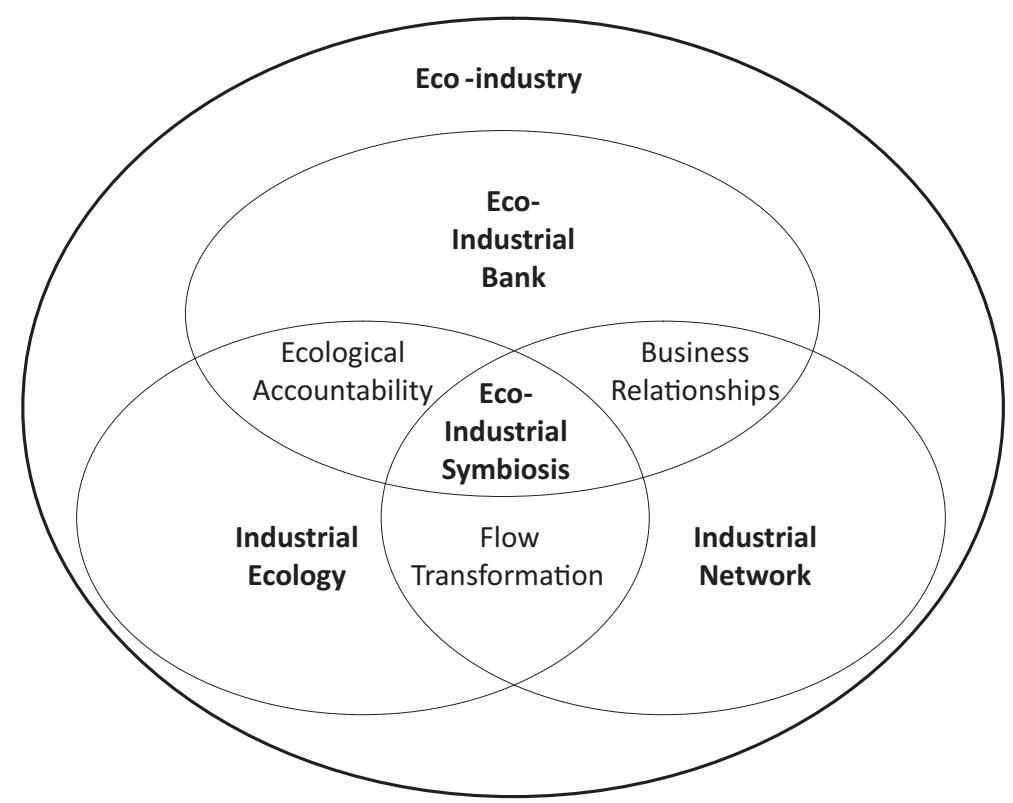

Figure 1. The role of eco-industrial bank in eco-industrial symbiosis

Source: own elaboration.

of effects could be observed. First of all, cost revenue payments for companies and bank from: infrastructure, marketing, transportation, and logistics development, efficient use of resources, effective emission and remedying pollution, appropriate management of waste water, solid waste, noise pollution, air pollution, efficient use of energy, eco-friendly processes, safety and health management, environmental monitoring, maintenance and improvement of the estate's management system, effective information and report management, and continuous improvement in the capability of personnel. Specialization reduces costs of bank's services and costs of stakeholders through adjustments and adoptions.

Secondly, the direct effect changing the potential of the relationship of eco-industrial bank as a lender and investor as a borrower. Bank and investors connect their resources. A relationship connects two heterogeneous collections of resources of the two parties - bank (takes deposits and sells securities or issues own securities) and investor (deposits money and buy securities). As it develops, the two companies direct and orient some of their resources towards each other. Adaptations are made in resource features and in the use combinations. A relationship between two com- panies can tie together more or less tightly some of their resources in a specific way.

The eco-industrial bank works to mobilize industrial actors to undertake activities and devote resources to implement network strategies of sustainable development. Therefore, the bank in eco-industrial network allows to develop activities, resources and actors combining business, society and ecology. In this way, the bank creates added value for the sustainable development playing the role of investor, financier, educator, adviser, promotor, and coordinator of ecoindustrial symbiosis. It is a nexus of stakeholders' relationships. It is particularly noticeable in connection between lending and green investments. The bank has to assess the credit risk of investment and later has to monitor the process of investing. The bank and the investor are bounded with the credit contract. Both bank and investors in business networks are never independent, isolated or alone. They are formed in their perceptions, knowledge, capabilities and intents by others.

And the last but not least the effects in the overall eco-industrial network like: collaboration among stakeholders, new eco-funds, eco-industrial banks, eco-industrial symbiosis, new eco-technologies, in- 
formation webs and trust and ethical, ecological and electronic money ( $E^{3}$ Money). In the network lending by bank interconnects stakeholders. It limits the freedom of stakeholders in using bank's money for another aim than sustainable business. These independencies provide a way for bank and stakeholders together to capitalize on the specific investments that they make in their own and each other resources. It serves for building of trust, commitment and reciprocity. Resource constellation overtime depicted as life cycle seems to be based on two basic features of the most resources of bank $\mathrm{E}^{3}$ Money. This money is created in sustainable bank and is being lent to sustainable business of stakeholders. Sustainable business is ethical, ecological and economic. Interaction enables heterogeneity of bank's resources to be exploiting as a means of value creation for stakeholders and bank. Actor webs link to co-evolution and jointness. Coevolution strengthens the trust, commitment, common motivation in solving problems for sustainable development. On the other hand jointness limits the autonomy of bank and stakeholders and requires interactions.

\section{CONCLUSIONS}

Separated fields of industrial sciences should work together more effectively on incorporating their achievements into common practice of sustainable development. More has to be done to explicate their structural and system aspects in common. The coalescence of all industrial knowledge into a unified whole is needed as well as more work is demanded to demonstrate the benefits of bringing industrial ecology into network practices. Up to day results, in form of the supply chain protocols for large-product oriented companies, required that suppliers to these companies carry out evaluation of environmental burdens associated with a product, process, or activity, are quite weak. To strengthen and accelerate the results of sustainable development joint academic and practical efforts should be undertaken within the frames of different considered industrial approaches. This broadening of industrial symbiosis requires new models of business and social relationships, finance flows, state regulations, and so on. This article applies to industrial ecology and industrial network theories and builds the model of eco-industrial symbiosis with the eco-industrial bank as an important participant transforming financial flows into sustainable development.

\section{REFERENCES}

1. Ayres, R.U., Ayres, L.W. (eds.) (2002). A handbook of industrial ecology. Edward Elgar, Cheltenham.

2. Azman, S. (2012). Green Corporate Environment Thru' Green Banking and Green Financing, The Financial Express, 4 July.

3. Bahl, S. (2012). Role of Green Banking in Sustainable Growth. International Journal of Marketing. Financial Services and Management Research, 2 (1), pp. 27-35.

4. Bai, Y. (2011). Financing a Green Future. An examination of China's banking sector for green finance. Masters Thesis, Lund University. IIIEE Theses 2011:02.

5. Baraldi, E., Gregori, G.L., Perna, A. (2010). Developing and embedding eco-sustainable solutions: the evolution of the Leaf House network. Paper presented at 26th International Marketing and Purchasing (IMP) Conference, Budapest, 02-04.09.2010.

6. Brundtland Commission (1987). Our Common Future. Oxford University Press, Oxford.

7. Bunjongsiri, K., Herat, S., Phung, T.D., Sivadechathep J., Chu, C. (2015). Eco-Industrial Park (EIP): Global Trends and Current Situation in Thailand. SAU Journal of Science \& Technology, 1 (2), pp. 47-63.

8. Chertow, M.R. (2000). Industrial symbiosis: Literature and taxonomy. Annual Review of Energy and Environment, 25, pp. 313-337.

9. Coalition for Green Capital (2014). Report. Green Bank Academy, Washington.

10. Desrochers, P. (2001). Cities and Industrial Symbiosis: Some Historical Perspectives and Policy Implications. Journal of Industrial Ecology, 5 (4), pp. 29-44.

11. Dornfeld, D.A. (ed.) (2012). Green Manufacturing, Fundamentals and Applications. Springer, New York.

12. Ehrenfeld, J. (2004). Industrial ecology: a new field or only a metaphor? Journal of Cleaner Production, 12 (8-10), pp. 825-831.

13. Ehrenfeld, J., Gertler, N. (1997). Industrial Ecology in Practice. The Evolution of Interdependence at Kalundborg. Journal of Industrial Ecology, 1 (1), pp. 67-79.

14. European Commission (2013). Financial support for energy efficiency in buildings. Report from the Commission to the European Parliament and The Council $\operatorname{COM}(2013) 225$ final. 
15. Ford, D., Håkansson, H. (2006). The Idea of Business Interaction. The IMP Journal, 1 (1), pp. 4-20.

16. Goyal, K.A., Joshi, V. (2011). A Study of Social and Ethical Issues in Banking Industry. International Journal of Economics and Research ,2 (5), pp. 49-57.

17. Habib, S.M.A. (2010). Green Banking: a Multi-stakeholder Endeavour. The Daily Star of 07.08.2010.

18. Håkansson, H., Ford., D. (2002). How should companies interact in business networks? Journal of Business Research, 55 (2), pp.133-139.Håkansson, H., Ford, D., Gadde, L-E., Snehota, I., Waluszewski, A. (2009). Business in Networks. John Wiley \& Sons, West Sussex.

19. Håkansson, H., Snehota, I. (eds.) (1995). Developing Relationships in Business Networks. Routledge, London-New York.

20. Håkansson, H., Waluszewski, A. (2002). Managing Technological Development, IKEA, the Environment and Technology. Routledge, London.

21. Iivonen, K. and J. Moisander. (2014). Rhetorical construction of narcissistic CSR orientation. Journal of Business Ethics, 131 (3), pp. 649-664.

22. Kakabadse, N.K., Rozuel, C., Lee-Davies, L. (2005). Corporate Social Responsibility and stakeholder approach: a conceptual review, International Journal of Business Governance and Ethics 1(4), pp. 277-302.

23. Kronenberg, J., Clift, R. (2005). Industrial Ecology in Poland. Journal of Industrial Ecology, 8 (4), pp. 13-17.

24. Kronenberg, J., Bergier, T. (2012). Sustainable development in a transition economy: business case studies from Poland. Journal of Cleaner Production, 26, pp. 18 27.

25. Lee, S. Y. and Carroll, C.E. (2011). The emergence, variation, and evolution of corporate social responsibility in the public sphere, 1980-2004: the exposure of firms to public debate. Journal of Business Ethics, 104 (1), pp. 115-131.

26. Li, Y., Shi, L. (2015). The Resilience of Interdependent Industrial Symbiosis Networks. A Case of Yixing Eco- nomic and Technological Development Zone. Journal of Industrial Ecology, 19 (2), pp. 264-273.

27. Lowe, E.A. (2001). Eco-Industrial Park Handbook for Asian Developing Countries, Report to Asian Development Bank. Indigo Development, Oakland.

28. Porter, T., Derry, R. (2012). Sustainability and business in a complex world, Business and Society Review, 117 (1), pp. 33-53.

29. Posch, A. (2010). Industrial Recycling Networks as Starting Points for Broader Sustainability-Oriented Cooperation? Journal of Industrial Ecology, 14 (2), pp. 242-257.

30. Rahman, S.M.M., Barua, S. (2016). The Design and Adoption of Green Banking Framework for Environment Protection: Lessons from Bangladesh. Australian Journal of Sustainable Business and Society, 2 (1), pp.1-19.

31. Schiller, F., Penn, A.S., Basson, L. (2014). Analyzing networks in industrial ecology - a review of SocialMaterial Network Analyses. Journal of Cleaner Production, 76, pp. 1-11.

32. Schultz, C. (2010). What is the Meaning of Green Banking? Green Bank Report, 2, pp. 127-131.

33. Singh, H., Singh, B.P. (2012). An Effective and Resourceful Contribution of Green Banking towards Sustainability. International Journal of Advances in Engineering Science and Technology, 1 (2), pp. 41-45.

34. Thombre, K.A. (2011). The New Face of Banking. Green Banking. Research Paper - Commerce, 1 (2), pp. $1-4$.

35. Velenturf, A.P.M., Jensen, P.D. (2015). Promoting Industrial Symbiosis. Using the Concept of Proximity to Explore Social Network Development. Journal of Industrial Ecology online version, pp. 1-10.

36. Verma, M.K. (2012). Green Banking: A Unique Corporate Social Responsibility of Indian Banks. International Journal of Research in Commerce and Management, 3 (1), pp. 110-114. 